\title{
Evaluating Options For The Regulation Of Payday Loans
}

\author{
Michael H. Anderson, University of Massachusetts Dartmouth, USA
}

Raymond Jackson, University of Massachusetts Dartmouth, USA

\begin{abstract}
This study discusses regulatory options that federal and state legislatures might consider for the payday loan industry. These options include outright prohibition; restricting the implicit annual percentage interest rate; limiting the amount per loan; limiting the number of concurrent loans; setting lower and upper limits on contract length; and defining the waiting period between loans. While other studies examining the payday loan industry have relied on user survey data or data from a specific lender, this study utilizes data collected by the administrative agent for all payday loan activity in several states, including Florida, Illinois, and Oklahoma. A comparison of key empirical results derived from the differing regulatory environments in these states provides guidance to those who consider imposing further regulation. The current regulatory constraints have resulted in a relatively low default rate, a high rate of loan denial, and a troubling industry reliance on the frequent borrower. An analytical framework is suggested for understanding the motivations of the low and high frequency borrowers.
\end{abstract}

Keywords: Payday Loans, Consumer Finance, Financial Regulation, Subprime Lending

\section{INTRODUCTION}

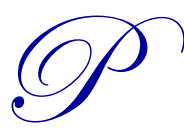

ayday loans are small, short-term loans made to individuals who in turn deliver to the lender a postdated check for the principal and interest. This post-dated check is frequently described in the regulatory literature as a deferred deposit. When the loan matures, presumably on the next payday when funds are available, the borrower's check is deposited for collection. The industry has seen significant growth since its inception in the early 1990s. According to the industry trade group Community Financial Services Association of America (2017), there are currently 20,600 payday advance locations in the U.S., providing $\$ 38.5$ billion in short-term credit to some 19 million households.

The typical payday loan amount is $\$ 300$ for a term of two weeks at a fee of $\$ 15$ per $\$ 100$ borrowed. Annualizing this cost leads to an annual percentage rate (APR) of 390\%. Resulting from such high implicit APRs, as well as from the perception that consumers become trapped in a cycle of payday loan borrowing, legislators in 15 states and the District of Columbia have effectively barred payday lenders from the state. They have done so by setting restrictive interest rate caps or through prohibition of lending secured by a deferred deposit (Pew Charitable Trusts, 2012). Nevertheless, according to industry critic Martin (2011), the continued success of the payday loan industry in states where conditions have allowed it to operate should place it on the short list of targets for the newly established Consumer Financial Protection Bureau (CFPB) — created as part of the 2010 Dodd-Frank Act.

In addition, the United States Department of Justice (DOJ) organized Operation Choke Hold in 2013 as an effort to deprive payday lenders of vital banking services (Wall Street Journal 2016). Using the regulatory powers of the Federal Deposit Insurance Corporation, the Comptroller of the Currency and the Federal Reserve, banks providing loans and services to payday lenders would receive additional scrutiny. The CFPB (2016) has also considered imposing regulations that would require payday lenders to consider a borrower's ability to repay, and that would deny approvals to borrowers who cannot afford full repayment of the loan when due.

Barring a change in consumer credit markets, any proposed restrictive regulations or limits on bank services to payday lenders would immediately impact those borrowers confronted with financial stress and seeking a 
convenient short-term loan. In 2010, over 12 million borrowers in the United States used funds derived from a payday loan (Pew Charitable Trusts, 2012).

The following sections consider the regulatory options that federal agencies such as the Consumer Finance Protection Bureau (CFPB) or state legislatures might impose on the payday loan industry, with the aim of providing guidance for the imposition of further regulations. These options include outright prohibition; restricting the implicit APR; limiting the amount per loan; limiting the number of concurrent loans; setting lower and upper limits on length; and extending the waiting period between loans. While most other studies examining the payday loan industry have relied on user survey data or data from a specific lender, this study extends the work of Anderson and Jackson (2010) by utilizing data collected by Veritec Solutions LLC, the state designated administrative agent for all payday loan activity in several states including Florida, Illinois, and Oklahoma.

\section{PROHIBITION OF THE PAYDAY BUSINESS MODEL}

There are two critical pieces to the business model of the payday lending industry: (1) the ability to make a small short-term loan at a relatively small fee, but one that translates into a very high APR, and (2) the lender's ability to secure the loan with a post-dated personal check from the borrower that covers both principal and fees. In states where payday lenders do not operate storefronts, this deferred deposit requirement is explicitly prohibited and/or the APR cap is set well below the rate at which payday lending is feasible. For example, New York State eliminated payday lending by disallowing the use of a post-dated personal check as the basis for a loan and by limiting the APR to $25 \%$. To comply with this APR cap, a two-week payday loan of $\$ 100$ would generate 96 cents of fee income to the lender.

At the federal level, the U.S. Congress effectively excluded lenders from offering a traditional payday loan to military personnel through the Military Authorization Act of 2007. The Act prohibits loans to members of the military with an APR exceeding $36 \%$, and further bans lenders from requiring a deferred deposit or other access to the borrower's account as security.

A number of industry studies have concluded that legislation to effectively eliminate payday lenders would provide substantial consumer benefits, despite removing a significant source of funds for those confronted with financial stress. For instance, Stegman and Faris (2003) conclude that the payday business model turned a significant number of consumers in North Carolina from occasional borrowers into chronic borrowers at high cost to themselves. Further, in a comparison of areas with and without borrower access to payday loans, Melzer (2011) find that access to payday lenders led to a number of negative consequences. Payday borrowers were less able to pay their mortgages and make timely rent and utility payments. They were also more likely to delay medical and dental care and less likely to make necessary prescription drug purchases.

On the other hand, studies have concluded that payday lending provides certain consumers with beneficial loans not available elsewhere. Edmiston (2011) notes that consumers in low-income areas without access to payday loans are forced to seek even more costly sources of credit. These costly alternative sources include loan sharks, pawnbrokers, cash advances on credit cards, and frequently resorting to defaulting on checks (i.e., having insufficient funds available). He reports that after payday lending was banned in Georgia and North Carolina, households defaulted more on checks, made more complaints to the FTC about lenders and debt collectors, and were more likely to file for bankruptcy. Fusaro (2008) estimates an implicit APR exceeding 4,000\% for funds obtained by a bounced check after all penalties and fees are assessed. In Oregon, restrictions on payday lending terms caused former payday borrowers to shift to bank overdrafts and late bill payments (Zinman 2010). In a similar vein, and using evidence from the financial impact of natural disasters in California, Morse (2011) concluded that the availability of payday loans mitigated the incidence of foreclosure and resulted in fewer larcenies-presumably due to the greater availably of legally obtainable funds. Lawrence and Elliehausen (2008) observed that the high satisfaction expressed by payday loan borrowers could be attributed to having greater control over their finances than they would otherwise have. 


\section{CONSTRAINTS ON PAYDAY LENDING}

Rather than outright prohibition, the majority of states have opted to regulate the payday loan industry in ways that allows it to continue, and in most cases, thrive. The usual forms of regulation involve some combination of limits on the (1) loan fee, (2) number of outstanding loans, (3) amount per loan, (4) minimum and maximum loan length, and (5) minimum idle time - the gap between paying off one loan and opening another. A comparison of the scope of regulation in Illinois, Florida, and Oklahoma is given in Table 1 (Appendix A). Florida sets the maximum fee at $10 \%$ of the loan amount, Illinois at $15.5 \%$, and Oklahoma has a sliding scale of $15 \%$ for the first $\$ 300$ and $10 \%$ of the loan amount above $\$ 300$.

The maximum loan size in Florida and Oklahoma is $\$ 500$ while in Illinois it is $\$ 1,000$. Both Oklahoma and Illinois allow a borrower to have two concurrent outstanding loans, while Florida allows only one-thus, the maximum indebtedness is $\$ 500$ in Florida and $\$ 1,000$ in the other two states. In Oklahoma, a borrower must wait 13 days after paying off one loan before she can open another. Wait periods are one day and seven days in Florida and Illinois, respectively. In addition, a second loan is denied in Illinois if the potential borrower has had a payday loan outstanding for 45 consecutive days or more. This wait time between loans is generally referred to as "the coolingoff period."

All three states specify certain considerations to a borrower in the event that a deferred deposit check is rejected due to insufficient funds. As detailed in Table 1, Florida and Illinois provide a grace period for repayment without added fees, while Oklahoma requires that lenders accept repayment on an arranged installment basis.

A common concern expressed about payday lending is the so-called credit trap. It may start with a very financially constrained consumer needing a short-term loan to then find that, given her tight budget, the only way to repay is to take out an additional loan - and she consequently becomes trapped in a seemingly endless cycle of borrowing. A mechanism to break this cycle would be invaluable to those in such circumstances; a provision to be able to convert into an installment loan — as in Oklahoma — would seem very desirable.

\subsection{Regulation of Loan Size}

Despite the variation in regulatory restrictions, the average loan amount is relatively stable within the $\$ 340-\$ 385$ range, as shown in Table 2 (Appendix A). As expected, the average loan amount in Florida is somewhat higher than the averages in Oklahoma and Illinois since only one outstanding loan at a time is allowed in Florida, as opposed to two in the other states. The ability to get a second loan in the near future in Oklahoma and Illinois reduces the incentive to get as close to the loan limit as possible.

The results also strongly suggest that a payday borrower may have a certain critical payment in mind when arranging for a loan - be it to pay for an emergency repair or to make a mortgage, rent, utility, or auto loan payment. The maximum loan limit in Illinois is $\$ 1,000$ - twice the limit in the other two states-yet the average loan size in Illinois remains comparable in the $\$ 340-\$ 385$ range. If regulators have a goal of reducing the average size of a payday loan, the limit would have to be set well below $\$ 500$, although a loan limit of $\$ 300$ or less may have adverse effects on the financial stability of these borrowers.

Restricting the size of subprime loans is also an effective way to reduce the risks from moral hazard and adverse selection. Adams, Einav, and Levin (2009) suggest that individual borrowers are more likely to default on larger loans due to moral hazard, because they do not internalize the full increase in default costs that arise as loan size increases. In addition, loan caps prevent high-risk borrowers from joining the client pool due to adverse selection. These borrowers would be attracted by the possibility of obtaining very large payday loans, which they are unlikely to repay.

\subsection{Limiting the Number of Outstanding Loans}

Although Florida restricts a borrower to one loan at a time, Oklahoma and Illinois allow for two concurrent loans. As expected, some consumers will choose to negotiate a second loan while still obligated for the first. Data collected 
from Oklahoma for 2006-2009 and presented in Table 3 (Appendix A) reveal that approximately $24 \%$ of borrowers reached the two-loan limit at some time during the year.

For borrowers with multiple loans outstanding, the average indebtedness far exceeds that for the borrower with one outstanding loan. For every month that data was collected, the second outstanding loan more than doubled the borrower's payday loan balance. For example, in March 2009, borrowers with one loan had an outstanding balance of $\$ 380.34$, while the outstanding balance for borrowers with two loans was $\$ 798.04$ as seen in Table 3 .

These findings indicate that a rule prohibiting concurrent payday loans would impact a significant share, but not the majority, of borrowers in states that currently permit up to two concurrent loans. Borrowers denied a second loan will likely not change the amount per loan, but may reduce by half their maximum outstanding payday loan debt during the year. Whether this step increases consumer welfare depends on the alternative strategies that these borrowers are forced to adopt to meet their financial needs, once denied a second payday loan.

There is some evidence that allowing a second concurrent payday loan puts additional stress on the ability of the borrower to repay. In Table 5 of Appendix A, the percentage of returned (bounced) checks and the percentage of loan losses to fees are shown for Florida and Oklahoma. Since Florida permits only one outstanding payday while Oklahoma allows two, we would expect that Florida would have fewer returned checks and a lower ratio of loan losses to fees. The results in Table 5 are mixed with regard to returned checks. For the Jan 2008 to May 2009 interval, $4.8 \%$ and $5.3 \%$ of checks were returned in Florida and Oklahoma, respectively. The numbers are exactly reversed for the Sept 2005-August 2006 interval. For the interval covering approximately mid-2006 to mid-2007, both states had a $4.8 \%$ returned check rate.

The results in Table 5 for the percentage of loan losses to fees are clearer. The loss ratio for Oklahoma is greater than Florida in all three time intervals, though the difference is declining. In the Sept 2005-Aug 2006 interval, the loss ratio in Oklahoma was $22.8 \%$, which was 3.1\% higher than in Florida. However, by June 2008-May 2009 it had fallen to $17.5 \%$, which was only $0.1 \%$ higher than Florida's. In the most recent time period, lender risk associated with payday loans, as measured by returned checks and loan losses, has not markedly increased by allowing two open loans rather than one.

Limiting both loan size and the number of concurrent loans places a strict limit on the maximum indebtedness of a payday borrower at any point in time. The maximum payday debt would be $\$ 500$ in Florida and $\$ 1,000$ in Illinois and Oklahoma. While some payday borrowers may struggle to break out of the cycle of payday indebtedness, these limits seem modest compared to recent estimates that households with credit card indebtedness have an average balance of $\$ 15,799$ (Woolsey and Shulz 2012). There is some evidence, measured by lender loan losses, that borrowers permitted to have up to two concurrent payday loans have greater difficulty to meet their financial obligations to the lender.

\subsection{Constraining Borrower Eligibility}

Eligibility for a payday loan is firstly determined by criteria set by the lender, and secondly by the state regulatory administration. A lender typically requires a borrower to be employed or have a steady income, a checking account, and be at least a certain age. For example, CashAdvance (2013), an online agent for multiple payday lenders, requires evidence of (1) employment for 90 days or more in the current job, (2) income of at least $\$ 1,000$ per month after taxes, (3) a valid checking account, (4) home and work phone numbers, and (5) age of at least 18 years.

For the three states included in this study, the loan application is sent on approval by the lender to the state's designated payday loan clearinghouse to determine whether the eligibility requirements described in Table 1 are met. A loan application would be rejected if it would exceed the maximum number of outstanding loans or the maximum loan amount, if it would be made prior to the end of the minimum waiting period, or if it would result in total outstanding payday loans exceeding the set maximum amount. In addition, an application for a second payday loan is denied in Illinois if the borrower has a loan that has been outstanding for 45 days or more. The declined eligibility ratios, measured as denied applications to total applications, are shown in Table 4 (Appendix A) for 
Florida, Illinois, and Oklahoma. For all three states, close to $20 \%$ of payday loan applications are deemed ineligible by the state regulatory administration.

Following state precedents, federal regulators may wish to set guidelines that states must follow regarding eligibility requirements such as extending the minimum waiting period between loans, establishing the maximum length of a loan, limiting the number of outstanding payday loans, and restricting the length of continuous time for which a borrower may have an outstanding payday loan. If deemed a positive step for public policy, more stringent requirements would certainly increase the current rejection ratio of $20 \%$ for loan applications in these states.

A decision to set national guidelines for a payday loan is plausible given the CFPB's efforts in the area of residential mortgages. It has completed the drafting of the terms for a standardized "qualified" mortgage (QM) that would certify that the agreement is fairly priced and the borrower has the ability to repay (Morgan, 2013). Extending this concept to the development of a "qualified" payday loan may follow, since major criticisms by consumer advocates of the payday loan industry are similar to those of subprime mortgage lenders in that loan terms are inherently "unfair, abusive, and deceptive" (Martin 2011).

\section{REGULATION AND LOAN FREQUENCY}

Advocates of the payday loan industry often emphasize the borrower's need for a readily available source of funds in an emergency, despite their high cost. Such a loan at a critical moment may allow a consumer to avoid the seriously disruptive consequences derived from missing a monthly mortgage, rent, utility, or auto loan payment, or from having an overdrawn bank account. In reality, access to payday lending as a loan of last resort during a period of financial crisis does not correspond to actual use by most of its borrowers. As shown in panel (a) of Table 6 for the 2007-2009 time period, relatively few borrowers negotiated only one loan during a year; these "emergency" borrowers accounted for a small percentage of the industry's business. For example, for the June 2008-May 2009 period, $15.1 \%$ of borrowers in Florida took out just one loan; these loans accounted for only $1.8 \%$ of the total loans made. During the April 2008-March 2009 period, 11.5\% of Oklahoma's borrowers took out one loan, and these loans accounted for only $1.2 \%$ of the total borrowed. A greater percentage $(25.3 \%)$ of borrowers in Illinois made one payday loan during February 2006-December 2008. These one-time borrowers still accounted for only $4.3 \%$ of the total loan volume.

The frequency statistics in panel (a) of Table 6 indicate that a payday loan is for many consumers far from an unusual event, and is integrated into their normal pattern of financial transactions. In Florida, 22.3\% of borrowers took out 10-15 payday loans during June 2008-May 2009. The percentage of borrowers with 10-15 loans in Oklahoma from April 2008-March 2009 was 22.9\%, and in Illinois from February 2006-December 2008 the percentage was $9.8 \%$.

The cumulative frequency statistics shown in panel (b) of Table 6 confirm the reliance of the payday loan industry on frequent repeat users for a major portion of its loan volume. In Florida, borrowers who took out 13 payday loans or more from June 2008-May 2009 represented $24.0 \%$ of borrowers but $52.0 \%$ of loan volume. Similar results are found in Oklahoma, where borrowers with 13 or more loans accounted for $26.8 \%$ of users but $54.3 \%$ of loans from April 2008-March 2009. The pattern in Illinois is consistent as borrowers with more than 13 loans from February 2006-December 2008 accounted for $13.1 \%$ of users, yet $44.8 \%$ of loan volume.

The repeated use of payday loans - even by households who hold credit cards - is perplexing to some observers. Agarwal, Paige, and Tobacman (2009) found in their dataset that a majority of payday borrowers with a major credit card still had substantial credit card liquidity available at the time of the payday loan. They speculate that consumers place high value on their remaining credit card liquidity, with payday loans used strategically to protect that liquidity despite their significant cost.

Strong evidence that many consumers rely on multiple payday loans during the year, and that the industry is dependent on these high-turnover consumers, is observed in all three states examined in this study. These phenomena appear to be unrelated to regulatory variations in the waiting period between loans, loan fees, number of outstanding loans permitted, and total continuous time allowed in a payday loan. Somewhat similar results were 
found by Kaufman (2013) using cross-sectional data from several states on loans from one payday lender. He found only modest reductions in loan frequency, with longer waiting periods and restrictions on the number of outstanding loans.

Our findings are somewhat different from Kaufman (2013) with respect to his emphasis on the importance of lower interest rate caps in increasing the frequency of the loan rate. As shown in Table 1, payday loans in Florida have lower interest rate caps as well as a shorter cooling-off period, and approximately the same term loan limit as those in Oklahoma. Based on these factors, following Kaufman (2013), Florida should have higher loan frequency rates than Oklahoma. However, the results in Table 6 for the 2008-2009 period show that $15.1 \%$ of Florida's borrowers made only one payday loan compared to $11.5 \%$ in Oklahoma; in addition, $2.3 \%$ of Florida borrowers had 25 or more payday loans compared to $4.6 \%$ in Oklahoma. The explanation for the lower borrower frequency rate at these extreme frequency levels is that Florida allows only one outstanding loan at a time while Oklahoma permits two. The restriction in Florida to allow only one outstanding loan appears to offset the state's lower interest caps and the shorter waiting time between loans.

A comparison of the frequency distribution of loans between Oklahoma and Illinois provides an important insight into future regulatory considerations on term limits. Both states have comparable rate caps and allow two outstanding loans and similar cooling-off periods, but have quite different term limits on a payday loan. Oklahoma restricts the term of a loan to a range of 12 to 15 days, while the proscribed range in Illinois is 13 to 120 days. The longer-term limit in Illinois appears to have a strong effect on the frequency distribution by allowing borrowers to stretch out the repayment rather than renewing or rolling over every two weeks. The results in Table 6 show that borrowers in Illinois with only one or two payday loans during the entire February 2006-December 2008 time period accounted for $52.4 \%$ of users, while borrowers who took out only one or two loans in Oklahoma during the shorter period from June 2006-May 2007 accounted for merely $29.9 \%$ of total users. Allowing states to extend the term limit on payday loans may reduce the incentive for borrowers to keep coming back for a renewal or rollover; however, longer term loans may well lead to higher delinquency rates as interest cost mounts.

Francis (2010) sees the repeat payday loan borrower as being overly optimistic, and as having imperfect self-control and a distorted sense of the discounting process (the time value of money). Her advice for the regulatory agency is to modify user behavior by providing a potential borrower with greater disclosure on the real cost and dangers of payday loans, information on the number of payday loans she has already negotiated, and distributing personal narratives of consumers who have been trapped into perpetual rollovers.

Although the frequency data raises public policy issues regarding the appropriate use of payday loans by repeat borrowers, it should be recognized that relatively few loans in Florida and Oklahoma go into default. The evidence on checks declined due to insufficient funds is presented in Table 5, where the return check rate as a percentage of total transactions ranges from $4.8 \%$ to $5.0 \%$ in Florida and from $4.8 \%$ to $5.3 \%$ in Oklahoma. This default rate is consistent with that of leading credit issuers as measured by the 2006 year-end $4.17 \%$ rate on Fitch's Prime Credit Card Chargeoff Index (Business Wire 2008). Despite the low default rate and high APRs on payday loans, lenders still have the incentive to proceed with caution in approving applications. As shown in Table 5, loan losses in each state represent a significant portion of fees collected, with the loss to fee ratio ranging from $17.4 \%$ in Florida to $22.8 \%$ in Oklahoma.

The presence of the high frequency borrower in a variety of state regulatory environments will certainly elicit a future response from state and federal regulators. Following Stegman and Faris (2003), regulators may encourage, or even require, credit unions, banks, and thrifts to supply consumer-friendly short-term loans that are "payday loanlike." It is not immediately clear how helpful this would be, since several key banks-including the Bank of America and Wells Fargo \& Co.-already offer a comparable product commonly referred to as a direct-deposit advance. With this product, the borrower receives the loan proceeds directly into a deposit account at the bank and then, at payday, the loan plus fees is automatically withdrawn from that account. While there is still the risk that the consumer could have lost their job in the interim, this product clearly has a lower default risk compared to a payday loan. 
Anderson and Jackson (2010) suggest an alternative framework for understanding the frequency of use statistics by segmenting the demand for payday loans into (1) emergency borrowers, (2) strategic borrowers, and (3) line-ofcredit borrowers. Any regulatory reforms must be cognizant of the role a payday loan has in meeting these needs. For a financially vulnerable household, a convenient payday loan may be essential to meet the expenses of an unexpected event. For the strategic borrower who may use a payday loan on a regular basis, it is often a costeffective alternative to defaulted check fees imposed by the bank and the check recipient, fees for late payment of credit card balances, and high upfront fees on credit card advances. The very high frequency user of payday loans in Oklahoma or Illinois, for example, effectively establishes a very costly $\$ 1,000$ line of credit for these consumers. Nevertheless, it is an indicator of the high value placed by the high-frequency borrower on maintaining a minimal level of liquidity. Payday loans are used to shield their remaining liquid assists or the unused portion of their credit card limit.

\section{CONCLUSION}

Proposals for additional federal and state intervention into the payday loan industry should consider the regulatory environments in Florida, Illinois, and Oklahoma, where lenders have met the demand for short-term funds by households with subprime credit while limiting the rate of default. Payday lenders can continue to operate payday loans within the context of industry-specific interest rate caps, limits on maximum loan size, waiting periods between loans, a limit on the number of loans outstanding and on continuous days. These restrictions do have a sharp impact on loan volume. Approximately $20 \%$ of loan applications in all three states are denied due to noncompliance with state regulations.

Limiting the number of outstanding payday loans to one loan would also affect a significant number of borrowers and reduce by half their maximum outstanding loan balance. Frequency of use evidence for all three states shows that the payday loan industry depends heavily on the high frequency borrower for income, rather than the borrower needing a loan for the rare emergency event. Regulators may address this issue by simply limiting the number of payday loans negotiated by a borrower during a calendar year or 12-month period. However, the cost of alternative sources of funds may result in a reduction of consumer welfare. There is some evidence that less restrictive term limits on a payday loan would reduce the number of loan renewals and roll-overs that generate these very high user frequency rates.

There are a number of ways to understand the high frequency borrower. Critics see this as evidence that the payday loan model is designed to catch consumers in a spiral of increasing debt. However, Edmiston (2011) finds that consumers with access to payday loans have higher credit standings than those without access. Anderson and Jackson (2010) suggest that the high frequency users treat their payday loans as a high-cost line of credit. Given that many payday loan borrowers have substantial credit card liquidity and other liquid assets, it appears that a payday loan may be seen by some consumers as a cost-effective option compared to other high-cost alternatives, and is being used strategically to maintain a critical level of liquidity.

\section{AUTHOR BIOGRAPHIES}

Professor Anderson's research interests include financial institutions, corporate finance, and game theory. Recent research has focused on subprime financing including rent-own agreement, payday lending, auto title loans, and pawn brokering.

Professor Jackson's primary research has been on the impact of regulation on economic welfare. Recent studies have examined the microeconomics of antitrust policy and the nature of contractual agreements entered into by financially constrained consumers. 


\section{REFERENCES}

Adams, W., Einav, L., \& Levin, J. (2009). Liquidity constraints and imperfect completion in subprime lending. American Economic Review, 99(1) 49-84.

Agarwal, S., Paige M. S., \& Tobacman, T. (2009). Payday loans and credit cards: new liquidity and credit card scoring puzzles. American Economic Review: Papers and Proceedings, 99(2) 412-417.

Anderson, M. H., \& Jackson R. (2010). Perspectives on payday loans: The evidence from Florida. Review of Business Research, 10(5) $154-161$.

Business Wire (2008). Fitch: Sizeable rise in loss rates has muted effect on U.S. credit card and auto ABS. February 1, 2008.

CashAdvance. (2013). How it works. Retrieved from http://www.cashadvance.com/get-started Community Financial Services Association of America. (2017). About the payday loan industry. Retrieved from http://cfsaa.com/about-the-paydayadvance-industry/survey-payday-loans-and-the-borrower-experience.aspx

Consumer Finance Protection Bureau. (2016). Consumer financial protection bureau proposes rule to end payday debt trap. Retrieved from https:/www.consumerfinance.gov/about-us/newsroom/consumer-financial-protection-bureau-proposesrule-end-payday-debt-traps/

Edmiston, K. (2011). Could restrictions on payday lending hurt consumers? Economic Review-Federal Reserve Bank of Kansas City, 63- 93. Retrieved from www.kc.frb.org/publicat/econrev/pdf/11q1Edmiston.pdf

Francis, K. (2010). Rollover, rollover: A behavioral law and economics analysis of the payday-loan industry. Texas Law Review, $88(3) 611-638$.

Fusaro, A. (2008). Hidden consumer loans: an analysis of implicit interest rates on bounced checks. Journal of Family and Economic Issues, 29(2) 251-263.

Kaufman, A. (2013). Payday lending regulation. (Board of Governors of the Federal Reserve System, Division of Research and Statistics, working paper 2013-62.)

Lawrence, E. C., \& Elliehausen, G. (2008). A comparative analysis of payday loan customers. Contemporary. Economic Policy 26(2) 299-316.

Martin, N. (2011). Regulating payday loans: why this should make the CFPB's short list. Harvard Business Law Review Online 44. Retrieved from www.hblr.org/?p=1595.

Melzer, B. (2011). The real costs of credit access: evidence from the payday lending market. The Quarterly Journal of Economics, 126(1) 517-555.

Morgan L. ( 2013). CFPB Issues Final Ability-to-Repay and Qualified Mortgage Rule. Retrieved from www.morganlewis.com/pubs/FS_LF_CFPBAbility-to-RepayQualifiedMortgage Rule_16jan13

Morse, A. (2011). Payday lenders: heroes or villains? Journal of Financial Economics, 102(1) $28-68$.

Pew Charitable Trusts. (2012). Payday lending in America: who borrows, where they borrow and why? Retrieved from www.pewstates.org/research/reports/who-borrows-where-they-borrow-and-why- 85899405043

Pew Charitable Trusts (2012). State payday loan regulation and usage rates. Retrieved from ww.pewstates.org/projects/safesmall-dollar-loans-research-project-328781

Stegman, M., \& Faris R. (2003). Payday lending: a business model that encourages chronic borrowing. Economic development Quarterly, 17(1) 8-32.

Veritec Solutions LLC. Florida trends in deferred presentment. Florida Office of Financial Regulation, January 2006, August 2007, July 2008, May 2009.

Veritec Solutions LLC. (2009). Illinois payday Loan Reform Act - Three Year Report. Illinois Division of Financial Institutions, March 2009.

Veritec Solutions LLC. Oklahoma trends in deferred deposit lending. Oklahoma Department of Consumer Credit, August 2006. May 2007, March 2009.

Wall Street Journal (2016). Government payday choke hold. Retrieved from www.wsj.com/articles/government-payday-chokehold-1482970562

Woolsey, B. \& Shulz, M. (2012). Credit card statistics, industry facts and debt statistics. Retrieved from www.creditcards.com/credit-card-news/credit-card-industry-facts-personal- debt-statistics

Zinman, J. (2010). Restricting consumer credit access: household survey evidence on effects around the Oregon rate cap. Journal of Banking and Finance, 34(3) 546-556. 


\section{APPENDIX A}

\section{Tables}

Table 1. Comparative Regulations of Payday Loans in Florida, Oklahoma, and Illinois

\begin{tabular}{|c|c|c|c|}
\hline Regulation & Florida & Oklahoma & Illinois \\
\hline Maximum Loan Size & $\$ 500$ & $\$ 500$ & $\$ 1000$ \\
\hline Maximum Open Loans & 1 & 2 & 2 \\
\hline Maximum Loan Balance & $\$ 500$ & $\$ 1000$ & $\$ 1000$ \\
\hline Loan Term Limits (days) & $7-31$ & $12-15$ & $13-120$ \\
\hline Minimum Waiting Period Between Loans (days) & 1 & 13 & 7 \\
\hline \multicolumn{4}{|l|}{ Maximum Marginal Interest Rate } \\
\hline$\$ 1-\$ 300$ & $10.0 \%$ & $15.0 \%$ & $15.5 \%$ \\
\hline$\$ 301-500$ & $10.0 \%$ & $10.0 \%$ & $15.5 \%$ \\
\hline Average & $\$ 3.00$ & $\$ 0.20$ & None \\
\hline \multicolumn{4}{|l|}{ Verification Fee 14 Day Loan APR } \\
\hline$\$ 100$ & $338.9 \%$ & $396.3 \%$ & $404.1 \%$ \\
\hline$\$ 300$ & $286.8 \%$ & $392.8 \%$ & $404.1 \%$ \\
\hline$\$ 500$ & $276.4 \%$ & $339.9 \%$ & $404.1 \%$ \\
\hline Non-Payment Options & $\begin{array}{c}60 \text { days grace } \\
\text { (no added fees) }\end{array}$ & $\begin{array}{l}\text { Installments } \\
\text { (added fees) }\end{array}$ & $\begin{array}{l}56 \text { days grace } \\
\text { (no added fees) }\end{array}$ \\
\hline
\end{tabular}

Source: Veritec Solutions LLC: Florida trends in deferred presentment (various years); Illinois trends in payday lending (October 2006); Oklahoma trends in deferred presentment (various years)

Table 2. Transactions, advances, and fees (comparable 12 month periods)

\begin{tabular}{|c|c|c|c|c|c|c|c|}
\hline State & $\begin{array}{c}\text { Period } \\
\text { Beginning }\end{array}$ & $\begin{array}{l}\text { Period } \\
\text { End }\end{array}$ & $\begin{array}{c}\text { Number of } \\
\text { Transactions }\end{array}$ & $\begin{array}{l}\text { Total Advance } \\
\text { (million \$) }\end{array}$ & $\begin{array}{l}\text { Total Fees } \\
\text { (million \$) }\end{array}$ & $\begin{array}{c}\text { Average } \\
\text { Loan }\end{array}$ & $\begin{array}{c}\text { Average } \\
\text { Fee/Loan }\end{array}$ \\
\hline Florida & June 2008 & May 2009 & $6,187,992$ & $\$ 2,380.0$ & $\$ 236.0$ & $\$ 384.55$ & $\$ 41.15$ \\
\hline Oklahoma & April 2008 & Mar 2009 & $1,058,067$ & $\$ 405.7$ & $\$ 54.3$ & $\$ 353.44$ & $\$ 54.30$ \\
\hline Illinois & Jan 2008 & Dec 2008 & 314,629 & $\$ 116.30$ & $\$ 17.9$ & $\$ 369.88$ & $\$ 57.02$ \\
\hline Florida & Sept 2006 & Aug 2007 & $5,847,840$ & $\$ 2,000.0$ & $\$ 216.0$ & $\$ 386.28$ & $\$ 41.52$ \\
\hline Oklahoma & June 2006 & May 2007 & $1,056,192$ & $\$ 383.10$ & $\$ 50.7$ & $\$ 362.89$ & $\$ 48.01$ \\
\hline Illinois & Jan 2007 & Dec 2007 & 382,407 & $\$ 140.00$ & $\$ 21.6$ & $\$ 365.69$ & $\$ 56.52$ \\
\hline Florida & Sept 2005 & Aug 2006 & $4,550,976$ & $\$ 1,730.0$ & $\$ 186.5$ & $\$ 381.25$ & $\$ 40.98$ \\
\hline Oklahoma & Sept 2005 & Aug 2006 & $1,021,829$ & $\$ 362.3$ & $\$ 47.8$ & $\$ 354.54$ & $\$ 46.93$ \\
\hline Illinois & Jan 2006 & Dec 2006 & 497,546 & $\$ 167.6$ & $\$ 25.6$ & $\$ 336.93$ & $\$ 51.58$ \\
\hline
\end{tabular}

Source: Veritec Solutions LLC: Florida trends in deferred presentment (various years); Illinois trends in payday lending (October 2006); LLC Oklahoma trends in deferred deposit lending (various years)

Table 3. The multiple outstanding loan factor in Oklahoma

\begin{tabular}{|c|c|c|c|c|c|c|c|}
\hline $\begin{array}{l}\text { Open } \\
\text { Loans }\end{array}$ & $\begin{array}{c}\text { Number } \\
\text { Borrowers }\end{array}$ & $\begin{array}{c}\% \\
\text { Borrowers }\end{array}$ & $\begin{array}{l}\text { Number } \\
\text { Loans }\end{array}$ & $\begin{array}{c}\% \\
\text { Loans }\end{array}$ & $\begin{array}{c}\text { Total Loan } \\
\text { Balance }\end{array}$ & $\begin{array}{l}\text { \% Total } \\
\text { Balance }\end{array}$ & $\begin{array}{l}\text { Average } \\
\text { Balance }\end{array}$ \\
\hline \multicolumn{8}{|c|}{ (a) March 2009} \\
\hline 1 & 83,295 & $77.7 \%$ & 83,295 & $63.6 \%$ & $\$ 31,680,162$ & $62.5 \%$ & $\$ 380.34$ \\
\hline 2 & 23,852 & $22.3 \%$ & 47,704 & $36.4 \%$ & $\$ 19,035,074$ & $37.5 \%$ & $\$ 798.04$ \\
\hline Total & 107,147 & $100.0 \%$ & 130,999 & $100.0 \%$ & $\$ 50,715,236$ & $100.0 \%$ & \\
\hline \multicolumn{8}{|c|}{ (b) May 2007} \\
\hline 1 & 73,713 & $75.9 \%$ & 73,713 & $61.2 \%$ & $\$ 27,209,105$ & $60.1 \%$ & $\$ 369.12$ \\
\hline 2 & 23,415 & $24.1 \%$ & 46,830 & $38.8 \%$ & $\$ 18,093,042$ & $39.9 \%$ & $\$ 772.21$ \\
\hline Total & 97,128 & $100.0 \%$ & 120,543 & $100.0 \%$ & $\$ 45,302,147$ & $100.0 \%$ & \\
\hline \multicolumn{8}{|c|}{ (c) August 2006} \\
\hline 1 & 68,105 & $76.2 \%$ & 68,105 & $61.5 \%$ & $\$ 24,633,102$ & $60.2 \%$ & $\$ 361.69$ \\
\hline 2 & 21,294 & $23.8 \%$ & 42,588 & $38.5 \%$ & $\$ 16,259,617$ & $39.8 \%$ & $\$ 763.58$ \\
\hline Total & 89,399 & $100.0 \%$ & 110,693 & $100.0 \%$ & $\$ 40,892,719$ & $100.0 \%$ & \\
\hline
\end{tabular}

Source: Veritec Solutions LLC: Oklahoma trends in deferred deposit lending (various years) 
Table 4. Declined loans to total applications

\begin{tabular}{l|c|c|c}
\hline \multicolumn{1}{c|}{ State } & $\begin{array}{c}\text { Period } \\
\text { Beginning }\end{array}$ & $\begin{array}{c}\text { Period } \\
\text { Ending }\end{array}$ & $\begin{array}{c}\text { \% Declined } \\
\text { Applications }\end{array}$ \\
\hline Florida & June 2008 & May 2009 & 18.7 \\
\hline Oklahoma & April 2008 & Mar 2009 & 17.1 \\
\hline Illinois & Mar 2007 & Feb 2008 & 20.0 \\
\hline Florida & Sept 2006 & Aug 2007 & 19.1 \\
\hline Oklahoma & June 2006 & May 2007 & 18.6 \\
\hline Illinois & Feb 2006 & Mar 2007 & 20.0 \\
\hline
\end{tabular}

Source: Veritec Solutions LLC: Florida trends in deferred presentment (various years); Illinois trends in payday lending (October 2006); Oklahoma trends in deferred deposit lending (various years)

Table 5. Returned checks and loan losses in Florida and Oklahoma

\begin{tabular}{l|c|c|c|c|c}
\hline \multicolumn{1}{c|}{ State } & $\begin{array}{c}\text { Period } \\
\text { Beginning }\end{array}$ & $\begin{array}{c}\text { Period } \\
\text { End }\end{array}$ & $\begin{array}{c}\text { Number of } \\
\text { Transactions }\end{array}$ & $\begin{array}{c}\text { Returned } \\
\text { Checks }\end{array}$ & $\begin{array}{c}\text { Loan Loss/ } \\
\text { Total Fees }\end{array}$ \\
\hline Florida & June 2008 & May 2009 & $6,187,992$ & $4.8 \%$ & $17.4 \%$ \\
\hline Oklahoma & April 2008 & Mar 2009 & $1,058,067$ & $5.3 \%$ & $17.5 \%$ \\
\hline Florida & Sept 2006 & Aug 2007 & $5,201,816$ & $4.8 \%$ & $19.2 \%$ \\
\hline Oklahoma & June 2006 & May 2007 & $1,056,192$ & $4.8 \%$ & $21.6 \%$ \\
\hline Florida & Sept 2005 & Aug 2006 & $4,550,976$ & $5.0 \%$ & $19.7 \%$ \\
\hline Oklahoma & Sept 2005 & Aug 2006 & $1,021,829$ & $4.8 \%$ & $22.8 \%$ \\
\hline
\end{tabular}

Source: Veritec Solutions LLC: Florida trends in deferred presentment (various years); Oklahoma trends in deferred deposit lending (various years) 
Table 6. Frequency and cumulative frequency distributions of payday loans

\begin{tabular}{|c|c|c|c|c|c|c|c|c|c|c|}
\hline \multicolumn{11}{|c|}{ (a)Frequency distribution of Use } \\
\hline \multirow{4}{*}{$\begin{array}{c}\text { Number } \\
\text { of } \\
\text { Loans }\end{array}$} & \multicolumn{10}{|c|}{ State } \\
\hline & \multicolumn{4}{|c|}{ Florida } & \multicolumn{4}{|c|}{ Oklahoma } & \multirow{2}{*}{\multicolumn{2}{|c|}{$\begin{array}{c}\text { Illinois } \\
\text { Feb 06-Dec } 08\end{array}$}} \\
\hline & \multicolumn{2}{|c|}{ June 08-May 09} & \multicolumn{2}{|c|}{ July 07-June 08} & \multicolumn{2}{|c|}{ April 08-Mar 09} & \multicolumn{2}{|c|}{ June 06-May 07} & & \\
\hline & $\begin{array}{c}\% \\
\text { Users }\end{array}$ & $\begin{array}{c}\% \\
\text { Loans }\end{array}$ & $\begin{array}{c}\% \\
\text { Users }\end{array}$ & $\begin{array}{c}\% \\
\text { Loans }\end{array}$ & $\begin{array}{c}\% \\
\text { Users }\end{array}$ & $\begin{array}{c}\% \\
\text { Loans }\end{array}$ & $\begin{array}{c}\% \\
\text { Users }\end{array}$ & $\begin{array}{c}\% \\
\text { Loans }\end{array}$ & \% Users & $\begin{array}{c}\% \\
\text { Loans }\end{array}$ \\
\hline 1 & 15.1 & 1.8 & 16.1 & 2.0 & 11.5 & 1.2 & 13.2 & 1.5 & 25.3 & 4.3 \\
\hline $2-3$ & 16.5 & 4.8 & 17.3 & 5.2 & 15.4 & 6.6 & 16.7 & 4.5 & 27.1 & 11.0 \\
\hline $4-6$ & 16.7 & 9.8 & 17.1 & 10.2 & 18.4 & 9.1 & 17.9 & 9.8 & 18.6 & 15.5 \\
\hline $7-9$ & 13.3 & 12.6 & 13.0 & 12.7 & 13.4 & 11.6 & 12.8 & 11.2 & 10.0 & 13.4 \\
\hline $10-12$ & 14.4 & 19.0 & 13.6 & 18.5 & 14.5 & 17.2 & 13.0 & 15.9 & 5.9 & 11.0 \\
\hline $13-15$ & 7.9 & 12.8 & 7.7 & 13.0 & 8.4 & 12.4 & 8.0 & 12.3 & 3.9 & 9.2 \\
\hline $16-18$ & 5.9 & 11.9 & 5.6 & 11.5 & 5.9 & 10.6 & 5.8 & 11.0 & 2.7 & 7.8 \\
\hline $19-21$ & 4.5 & 10.6 & 4.3 & 10.5 & 4.8 & 10.3 & 4.8 & 10.6 & 1.8 & 6.1 \\
\hline $22-24$ & 3.4 & 9.6 & 3.3 & 9.3 & 3.1 & 7.8 & 3.2 & 8.0 & 1.3 & 5.0 \\
\hline $25+$ & 2.3 & 7.1 & 2.0 & 7.1 & 4.6 & 13.2 & 4.6 & 15.2 & 3.4 & 16.7 \\
\hline & 100.0 & 100.0 & 100.0 & 100.0 & 100.0 & 100.0 & 100.0 & 100.0 & 100.0 & 100.0 \\
\hline
\end{tabular}

(b) Cumulative Frequency Distribution of Use

\begin{tabular}{|c|c|c|c|c|c|c|c|c|c|c|}
\hline \multirow[b]{4}{*}{$\begin{array}{c}\text { Number of } \\
\text { Loans }\end{array}$} & \multicolumn{10}{|c|}{ State } \\
\hline & \multicolumn{4}{|c|}{ Florida } & \multicolumn{4}{|c|}{ Oklahoma } & \multirow{2}{*}{\multicolumn{2}{|c|}{$\begin{array}{c}\text { Illinois } \\
\text { Feb 06-Dec } 08\end{array}$}} \\
\hline & \multicolumn{2}{|c|}{ June 08-May 09} & \multicolumn{2}{|c|}{ July 07-June 08} & \multicolumn{2}{|c|}{ April 08-March 09} & \multicolumn{2}{|c|}{ June 06-May 07} & & \\
\hline & $\begin{array}{c}\% \\
\text { Users }\end{array}$ & $\begin{array}{c}\% \\
\text { Loans }\end{array}$ & $\begin{array}{c}\% \\
\text { Users }\end{array}$ & $\begin{array}{c}\% \\
\text { Loans }\end{array}$ & $\begin{array}{c}\% \\
\text { Users }\end{array}$ & $\begin{array}{c}\% \\
\text { Loans }\end{array}$ & $\begin{array}{c}\% \\
\text { Users }\end{array}$ & $\begin{array}{c}\% \\
\text { Loans }\end{array}$ & $\begin{array}{c}\% \\
\text { Users }\end{array}$ & $\begin{array}{c}\% \\
\text { Loans }\end{array}$ \\
\hline 1 & 15.1 & 1.8 & 16.1 & 2.0 & 11.5 & 1.2 & 13.2 & 1.5 & 25.3 & 4.3 \\
\hline $2-3$ & 31.6 & 6.6 & 33.4 & 7.2 & 26.9 & 7.8 & 29.9 & 6.0 & 52.4 & 15.3 \\
\hline $4-6$ & 48.3 & 16.4 & 50.5 & 17.4 & 45.3 & 16.9 & 47.8 & 15.8 & 71.0 & 30.8 \\
\hline $7-9$ & 61.6 & 29.0 & 63.5 & 30.1 & 58.7 & 28.5 & 60.6 & 27.0 & 81.0 & 44.2 \\
\hline $10-12$ & 76.0 & 48.0 & 77.1 & 48.6 & 73.2 & 45.7 & 73.6 & 42.9 & 86.9 & 55.2 \\
\hline $13-15$ & 83.9 & 60.8 & 84.8 & 61.6 & 81.6 & 58.1 & 81.6 & 55.2 & 90.8 & 64.4 \\
\hline $16-18$ & 89.8 & 72.7 & 90.4 & 73.1 & 87.5 & 68.7 & 87.4 & 66.2 & 93.5 & 72.2 \\
\hline $19-21$ & 94.3 & 83.3 & 94.7 & 83.6 & 92.3 & 79.0 & 92.2 & 76.8 & 95.3 & 78.3 \\
\hline $22-24$ & 97.7 & 92.9 & 98.0 & 92.9 & 95.4 & 86.8 & 95.4 & 84.8 & 96.6 & 83.3 \\
\hline $25+$ & 100.0 & 100.0 & 100.0 & 100.0 & 100.0 & 100.0 & 100.0 & 100.0 & 100.0 & 100.0 \\
\hline
\end{tabular}

Source: Veritec Solutions LLC Florida trends in deferred presentment (various years); Illinois trends in payday lending (October 2006); Veritec Solutions LLC Oklahoma trends in deferred deposit lending (various years) 


\section{NOTES}

